\title{
Application of positive matrix factorization to on-road measurements for source apportionment of diesel- and gasoline-powered vehicle emissions in Mexico City
}

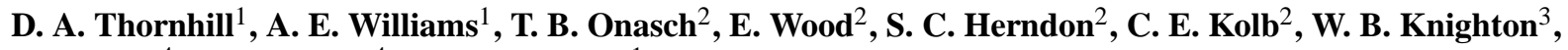 \\ M. Zavala ${ }^{4}$, L. T. Molina ${ }^{4}$, and L. C. Marr ${ }^{1}$ \\ ${ }^{1}$ Department of Civil and Environmental Engineering, Virginia Tech, Blacksburg, VA, USA \\ ${ }^{2}$ Aerodyne Research Inc., Billerica, MA, USA \\ ${ }^{3}$ Department of Chemistry and Biochemistry, Montana State University, Bozeman, MT, USA \\ ${ }^{4}$ Molina Center for Energy and the Environment, La Jolla, CA and Department of Earth, Atmospheric, and Planetary \\ Sciences, Massachusetts Institute of Technology, Cambridge, MA, USA
}

Received: 18 November 2009 - Published in Atmos. Chem. Phys. Discuss.: 21 December 2009

Revised: 2 April 2010 - Accepted: 9 April 2010 - Published: 20 April 2010

\begin{abstract}
The goal of this research is to quantify dieseland gasoline-powered motor vehicle emissions within the Mexico City Metropolitan Area (MCMA) using on-road measurements captured by a mobile laboratory combined with positive matrix factorization (PMF) receptor modeling. During the MCMA-2006 ground-based component of the MILAGRO field campaign, the Aerodyne Mobile Laboratory (AML) measured many gaseous and particulate pollutants, including carbon dioxide, carbon monoxide $(\mathrm{CO})$, nitrogen oxides $\left(\mathrm{NO}_{\mathrm{x}}\right)$, benzene, toluene, alkylated aromatics, formaldehyde, acetaldehyde, acetone, ammonia, particle number, fine particulate mass $\left(\mathrm{PM}_{2.5}\right)$, and black carbon (BC). These serve as inputs to the receptor model, which is able to resolve three factors corresponding to gasoline engine exhaust, diesel engine exhaust, and the urban background. Using the source profiles, we calculate fuel-based emission factors for each type of exhaust. The MCMA's gasoline-powered vehicles are considerably dirtier, on average, than those in the US with respect to $\mathrm{CO}$ and aldehydes. Its diesel-powered vehicles have similar emission factors of $\mathrm{NO}_{\mathrm{x}}$ and higher emission factors of aldehydes, particle number, and BC. In the fleet sampled during AML driving, gasoline-powered vehicles are found to be responsible for $97 \%$ of total vehicular emissions of $\mathrm{CO}, 22 \%$ of $\mathrm{NO}_{\mathrm{x}}$, 95-97\% of each aromatic species, $72-85 \%$ of each carbonyl species, $74 \%$ of ammonia, negligible amounts of particle
\end{abstract}

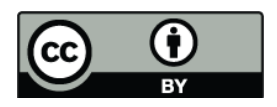

Correspondence to: L. C. Marr (lmarr@vt.edu) number, $26 \%$ of $\mathrm{PM}_{2.5}$, and $2 \%$ of $\mathrm{BC}$; diesel-powered vehicles account for the balance. Because the mobile lab spent $17 \%$ of its time waiting at stoplights, the results may overemphasize idling conditions, possibly resulting in an underestimate of $\mathrm{NO}_{\mathrm{x}}$ and overestimate of $\mathrm{CO}$ emissions. On the other hand, estimates of the inventory that do not correctly account for emissions during idling are likely to produce bias in the opposite direction.The resulting fuel-based estimates of emissions are lower than in the official inventory for $\mathrm{CO}$ and $\mathrm{NO}_{\mathrm{x}}$ and higher for VOCs. For $\mathrm{NO}_{\mathrm{x}}$, the fuel-based estimates are lower for gasoline-powered vehicles but higher for diesel-powered ones compared to the official inventory. While conclusions regarding the inventory should be interpreted with care because of the small sample size, $3.5 \mathrm{~h}$ of driving, the discrepancies with the official inventory agree with those reported in other studies.

\section{Introduction}

The rapid growth and development of the Mexico City Metropolitan Area (MCMA) over the past 30-40 years has led to a commensurate increase in pollutant sources within the transportation sector that has significantly impacted air quality in the region. MCMA government authorities are continuing their efforts to curb mobile source emissions. In 1985 , less than $1 \%$ of cars in the MCMA had catalytic converters, and by 1999 , this fraction had risen to $65 \%$ as a direct result of a law which required two-way catalytic converters beginning with model-year 1991 vehicles and three-way

Published by Copernicus Publications on behalf of the European Geosciences Union. 
catalytic converters beginning with model-year 1993 vehicles (Molina and Molina, 2002). There have also been significant improvements in the inspection and maintenance of vehicles throughout the MCMA. The benefits of stringent emission control standards and technological advancements in fuels and vehicles are undeniable (Kirchstetter et al., 1999b; Sawyer et al., 2000). Such improvements have been responsible for reducing mobile source emissions, or at least preventing them from growing in the face of an increasing number of vehicles on the road and distances driven (Zavala et al., 2009b). Despite its efforts, the MCMA still experiences serious air pollution problems with many pollutants regularly exceeding Mexican and US air quality standards.

Motor vehicles are the dominant source of emissions of regulated pollutants in most megacities, including the MCMA. Mexico's official emission inventory for 2006 suggests that transportation was responsible for $99 \%$ of carbon monoxide $(\mathrm{CO}), 82 \%$ of nitrogen oxides $\left(\mathrm{NO}_{\mathrm{x}}\right), 34 \%$ of volatile non-methane organic compounds (VOCs), $23 \%$ of coarse particulate matter $\left(\mathrm{PM}_{10}\right), 62 \%$ of fine particulate matter $\left(\mathrm{PM}_{2.5}\right)$, and $48 \%$ of sulfur dioxide $\left(\mathrm{SO}_{2}\right)$ emissions (SMA, 2008a). Even though diesel-powered vehicles accounted for less than $6 \%$ of all vehicles, they were estimated to be responsible for over $78 \%$ of $\mathrm{PM}_{2.5}$ and $31 \%$ of $\mathrm{NO}_{\mathrm{x}}$ emissions from mobile sources, if all "autobuses" (i.e., large intercity coaches, in contrast to smaller, mostly intracity "microbuses") are assumed to run on diesel fuel.

Emissions from gasoline- versus diesel-powered vehicles differ enormously by pollutant, and activity patterns of the two vehicle types differ by time of day and day of week (Marr et al., 2002). Therefore, distinguishing between them is important from the standpoint of air quality management. For mobile sources, $\mathrm{CO}$ and VOC are mainly associated with gasoline-powered engines, $\mathrm{PM}_{2.5}$ with diesel-powered engines, and $\mathrm{NO}_{\mathrm{x}}$ with both. Differences in combustion conditions for each of the fuels and in their physicochemical properties are the primary cause for the distinctions. A second reason for the difference is that, at present, there are more stringent controls on light-duty gasoline-powered cars than on heavy-duty diesel-powered trucks and buses. As a result, the development of effective control strategies focusing on mobile sources must accurately distinguish between emissions from the two major engine types.

Validation of emission inventories through independent measurements is a critical step in air quality management. Mexico uses a customized version of the US Environmental Protection Agency's MOBILE program that incorporates locally measured emission factors to develop its official inventory. We have been using the Aerodyne Mobile Laboratory (AML) (Kolb et al., 2004) to characterize emissions in the MCMA and other locations under real-world driving conditions across a wide variety of in-use vehicles. The AML is equipped with a suite of fast gaseous and particulate analyzers capable of operating during driving. Using measurements from a field campaign in 2003, we developed an alternative mobile source emission inventory for the MCMA (Jiang et al., 2005; Zavala et al., 2006). Compared to the government's official inventory, the estimates for $\mathrm{CO}$ and $\mathrm{NO}_{\mathrm{x}}$ were 20 $40 \%$ lower, and those for VOCs and $\mathrm{PM}_{2.5}$ were 20-30\% higher. In 2006, the AML was deployed in Mexico City again as part of the ground-based MCMA-2006 component of the large field campaign, Megacity Initiative: Local and Global Research Observations (MILAGRO). New, faster CO and $\mathrm{NO}_{\mathrm{x}}$ analyzers on the AML enabled improved quantification of emissions.

Previous work has employed two different approaches to deriving emission factors from on-road measurements collected by the AML (Canagaratna et al., 2004; Herndon et al., 2005a, b; Jiang et al., 2005; Shorter et al., 2005; Zavala et al., 2006, 2009a, b). In the first, known as the "chasing" technique, individual vehicles are targeted, and pollutant concentrations in plumes intercepted during the chase are subsequently analyzed to determine emission factors. Although this method is able to identify individual vehicle types (e.g., heavy-duty diesel truck versus gasoline-powered taxi), it is highly labor intensive and therefore limited in terms of the vehicle sample size. In the second approach, dubbed the "fleet-average" technique, the AML is considered to be continually sensing exhaust plumes from the vehicles around it. In this mode, all time series data points that are associated with exhaust plumes can be used - minus those contaminated by the AML's own exhaust - to develop emission factors representative of an ensemble of on-road vehicles. Further screening by speed can allow characterization of emissions as a function of driving conditions (Zavala et al., 2009b). This method allows more automated processing of data but is not able to distinguish between vehicle types without additional video analysis. Here, we present a third approach that applies positive matrix factorization (PMF) to resolve gasoline engine exhaust from diesel and to calculate emission factors associated with each fuel.

PMF has been used extensively as a means of source apportionment (e.g., Kim et al., 2004; Lee et al., 2006; Paterson et al., 1999; Pekney et al., 2006). In a study of polycyclic aromatic hydrocarbons in ambient air in Baltimore, Larsen et al. (2003) identified PMF as the only one among three source apportionment methods with the ability to isolate gasoline from diesel sources. Applying PMF to one-hour gaseous and particulate concentrations from a stationary site in southern California, Grover and Eatough (2008) derived six factors, including one attributed to gasoline-powered vehicle emissions and one to the diesel counterpart.

Only a limited number of studies have determined emissions from both gasoline- and diesel-powered vehicles under a variety of on-road driving conditions. The main objective of this study is to quantify emission factors from both gasoline- and diesel-powered vehicles in the MCMA. The AML offers the advantage of real-time measurement of emissions over the full range of on-road driving conditions, without being confined to a single site along a roadway or relying 
Table 1. Species used in the positive matrix factorization and their limits of detection and relative uncertainties during mobile measurements with the AML.

\begin{tabular}{|c|c|c|c|}
\hline Species & Instrument/method & Limit of detection ${ }^{\mathrm{a}}$ & Uncertainty $^{\mathrm{b}}$ \\
\hline Carbon monoxide $(\mathrm{CO})$ & $\begin{array}{l}\text { Aerodyne quantum cascade tunable infrared } \\
\text { laser differential absorption spetrometer } \\
(\text { QC-TILDAS })^{c}\end{array}$ & $6 \mathrm{ppb}$ & $8 \%$ \\
\hline Nitric oxide $(\mathrm{NO})^{\mathrm{d}}$ & EcoPhysics $88 \mathrm{Y}$ chemiluminescence detector & $3 \mathrm{ppb}$ & $7 \%$ \\
\hline Nitrogen dioxide $\left(\mathrm{NO}_{2}\right)^{\mathrm{d}}$ & QC-TILDAS & $1 \mathrm{ppb}$ & $8 \%$ \\
\hline Formaldehyde (HCHO) & QC-TILDAS & $1 \mathrm{ppb}$ & $8 \%$ \\
\hline Acetaldehyde (Acetald) & $\begin{array}{l}\text { Proton transfer reaction mass spectrometer } \\
\text { (PTR-MS) }\end{array}$ & $1.7 \mathrm{ppb}$ & $25 \%$ \\
\hline Acetone (Acet) & PTR-MS & $0.7 \mathrm{ppb}$ & $25 \%$ \\
\hline Benzene (Ben) & PTR-MS & $0.7 \mathrm{ppb}$ & $25 \%$ \\
\hline Toluene (Tol) & PTR-MS & $0.4 \mathrm{ppb}$ & $25 \%$ \\
\hline Fine particulate matter $\left(\mathrm{PM}_{2.5}\right)$ & TSI DustTrak 8520 aerosol photometer & $1 \mu \mathrm{g} \mathrm{m}^{-3}$ & $15 \%$ \\
\hline Black carbon $(\mathrm{BC})$ & Thermo Multi-angle Absorption Photometer 5012 & $0.01 \mu \mathrm{g} \mathrm{m}^{-3 \mathrm{f}}$ & $12 \%$ \\
\hline
\end{tabular}

${ }^{\mathrm{a}}$ For a signal-to-noise ratio of 2 at $1 \mathrm{~Hz} ;{ }^{\mathrm{b}}$ One standard deviation; ${ }^{\mathrm{c}}$ Nelson et al. (2004); ${ }^{\mathrm{d}} \mathrm{NO}_{\mathrm{x}}=\mathrm{NO}+\mathrm{NO}_{2}$; ${ }^{\mathrm{e}}$ Rogers et al. $(2006)$;

${ }^{\mathrm{f}}$ For a 30-min averaging time (Petzold and Schonlinner, 2004).

on offline chemical analyses. To resolve vehicle emissions from background air pollution, we apply PMF to on-road data collected by the AML during the MCMA-2006 field campaign. To our knowledge, this is the first time that PMF has been applied to fast, on-road data. Given the small size of the data set, this work can be considered an initial application or test of the approach. From the resulting source profiles, we then calculate fuel-based emission factors and estimate the total motor vehicle emission inventory for the MCMA. By providing alternative estimates of vehicle emissions in Mexico City, the results of this work will contribute to the current understanding of emission factors and inventories and their associated uncertainties.

\section{Methods}

The Aerodyne Mobile Lab (AML) (Kolb et al., 2004), designed and built by Aerodyne Research Inc., was equipped with a suite of fast-response analyzers that measure the gases and particles listed in Table 1 at a 1-s sampling interval. Between 2003 and 2006, upgrades to the instruments on the AML allowed faster measurement of $\mathrm{CO}$ and $\mathrm{NO}_{\mathrm{x}}$. Environmental conditions such as wind speed, pressure, temperature, and relative humidity were also measured continuously, and a video camera recorded the view ahead, providing a record of surrounding traffic conditions, types of vehicles, and pos- sible emission sources. The aerosol photometer for measuring $\mathrm{PM}_{2.5}$ mass used the factory calibration for Arizona Test Dust. Based on previous gravimetric calibrations of the $\mathrm{PM}_{2.5}$ analyzer in Mexico City (Jiang et al., 2005), we multiplied the factory-calibrated output by 0.34 . Because the optical properties of $\mathrm{PM}_{2.5}$ depend strongly on the size distribution and chemical composition of the particles, the values reported here should be viewed as only semi-quantitative.

In contrast to the MCMA-2003 field campaign, during which the AML was deployed on city streets and highways on most days, in 2006, the AML focused on stationary-site measurements, and parked at fixed locations for periods of 2-12 days. However, driving between sites presented the opportunity to sample exhaust emissions from surrounding vehicles on the roadway. This study focuses on a drive between the Universidad Technológica de Tecámac (T1 supersite) in the northeastern part of the MCMA and Santa Ana south of the city on 22 March 2006. The distance between the two sites is approximately $75 \mathrm{~km}$, and driving took place from 11:00 until 14:30. During this period, the AML encountered a wide range of conditions, from idling in traffic at stoplights to navigating two- and four-lane roads to cruising along multi-lane highways. Based on manual counts of vehicles for 5 out of every $15 \mathrm{~min}$, we estimate that the AML passed or was passed by 380 vehicles and that $\sim 8 \%$ of these were diesel-powered. To the experienced team of 
researchers, nothing was overtly unusual about the road, driving conditions, or vehicle fleet encountered on this day compared to others. Drives on other days during the field campaign were too short for analysis, lacked sufficient traffic, and/or were subject to rain.

Quality assurance and control of the measurements included routine calibration of the analyzers, overblowing the inlet with "zero" air every five minutes, removal of potential self-sampling data points when the wind was blowing from the rear of the AML, and precise alignment of all time series by visual inspection.

To conduct the source apportionment, we used the United States Environmental Protection Agency's (EPA) PMF 3.0 receptor model, which is based on the Multilinear Engine 2 program (Paatero, 1999). The model assumes that concentrations at a receptor (the AML in this case) are linear combinations of different sources and solves for both the source profiles and their fractional contributions to the observations at each point in time:

$x_{i j}=\sum_{k=1}^{p} g_{i k} f_{k j}+e_{i j}$

where $x_{i j}$ is the observed concentration of species $j$ at the $i$ th observation in time; $k$ is a factor (source) up to a total of $p$ sources, where $p$ is specified by the user; $g_{i k}$ is the fractional contribution of source $k$ at the $i$-th observation in time; $f_{k j}$ is the fraction of the $k$-th factor that is species $j$; and $e_{i j}$ is the residual. The matrix $\mathbf{G}$, then, contains the time series of relative contributions of each source to the observation, and F contains the source profiles. The objective function to be minimized by PMF is:

$Q=\sum_{i=1}^{n} \sum_{j=1}^{m} \frac{e_{i j}^{2}}{s_{i j}^{2}}$

where $i$ runs from the first measurement in time to $n=3953$ in our case, $j$ is one of 13 species appearing in Table 1 with $\mathrm{NO}$ and $\mathrm{NO}_{2}$ summed to $\mathrm{NO}_{\mathrm{x}}$ and black carbon excluded, and $s_{i j}$ is:

$s_{i j}=\sqrt{\left(u_{j} x_{i j}\right)^{2}+\operatorname{lod}_{j}^{2}}$

where $u_{j}$ and $\operatorname{lod}_{j}$ are the uncertainty and limit of detection, respectively, associated with each species. If the measured concentration is less than the limit of detection, then $u_{i j}$ is assigned the value of $5 / 6$ of $\operatorname{lod}_{j}$. The limits of detection and relative uncertainties for each species are based on manufacturers' specifications, calibration gas accuracies, and researchers' experience with the analyzers.

Following recommendations from a study of noise in factor analysis (Paatero and Hopke, 2003), we designated ammonia as a "weak" species within the modeling program because of its relatively low signal-to-noise ratio of 0.89 . The model then triples this species' uncertainty. We tested 20 random starting points to ensure identification of the global minimum. In theory, $Q$ will be roughly equal to the number of elements of the matrix $\mathbf{X}$ (i.e., the product of $i$ and $j$ ), or 51389 in this study. Because the black carbon (BC) analyzer had a slower sampling interval of $2 \mathrm{~s}$, we treated it separately from the other species and calculated its source profile after obtaining PMF results. We ran a multiple linear regression of the measured concentrations of BC against the factor contributions, $g_{i k}$ in Eq. (1), which were derived by PMF, to solve for the $\mathrm{BC}$ source profiles.

To quantify uncertainty in the derived source profiles, we used the PMF model's bootstrapping capability with 500 runs and a minimum correlation coefficient of 0.6 for mapping of the bootstrap factors to the base factors. To address rotational freedom in the solution, we examined correlations between the time series of different factor contributions in "G-space" plots (Paatero et al., 2005). A lack of "edges" in the scatterplots between any two factors suggests that unrealistic rotations are not present in the solution. Furthermore, we imposed rotations in the solution by adjusting the model's FPEAK rotational parameter between -1 and +1 and then inspected the resulting G-space plots for improved results.

PMF requires careful interpretation of the results to ensure their physical and chemical significance. We hypothesized that we would be able to resolve at least three source factors in the on-road data: background, gasoline engine exhaust, and diesel engine exhaust. The background is defined as ambient air in the absence of vehicular emissions. It encompasses local industrial, commercial, and residential sources, as well as transported pollution. We also attempted to resolve multiple background factors and to isolate raw gasoline engine exhaust from that treated by a catalytic converter. In running the model, we systematically varied the number of factors between three and five. Interpretability was a main criterion in judging results, as used in other studies (e.g., Shrivastava et al., 2007) and recommended in a review of PMF methods (Reff et al., 2007). We evaluated the absolute and relative concentrations in each of the factors and compared the time series of source contributions against the video recording of the surrounding traffic. For example, the $\mathrm{CO}_{2}$ mixing ratio in any background factors should sum to $\sim 380 \mathrm{ppm}$, and a gasoline factor could be identified by relatively higher $\mathrm{CO}$ and benzene compared to $\mathrm{PM}_{2.5}$. Furthermore, any background factor's time series should be more constant than those associated with vehicles, which would show spikes when the AML happened to be sampling an exhaust plume. While all instruments listed in Table 1 and used in the PMF analysis had a sampling rate of $1 \mathrm{~s}$, their true time response varied from less than $1 \mathrm{~s}$ to $\sim 30 \mathrm{~s}$ (e.g., TSI model 3022a CPC). This variation in time response has potentially important implications for PMF analysis and the discrimination between minor source factors.

To calculate emission factors in units of grams of pollutant per liter of fuel, we applied a mass balance on carbon (Jiang et al., 2005; Singer and Harley, 2000) to the source profiles derived by PMF. Mass fractions of carbon 
in the fuel were 0.87 for both gasoline (Schifter et al., 2005) and diesel fuel (Kirchstetter et al., 1999a). The calculation required an estimate of VOC emissions to completely balance carbon in the fuel. Because the PTR-MS provided measurements of certain organic compounds but not the total, we scaled benzene by a VOC/benzene ratio of $69 \pm 7 \mathrm{ppb} \mathrm{Cpp} \mathrm{C}^{-1}$ (mean \pm standard error) measured in 60 VOC canisters collected on the AML while driving in Mexico City in 2003 (Velasco et al., 2007). We assumed a molecular weight of $14 \mathrm{~g} \mathrm{~mol} \mathrm{C}^{-1}$ for the VOC mixture, resulting in a VOC/benzene mass ratio of 74 . These assumptions are reasonable, but not critical, because VOCs accounted for only $5 \%$ of carbon in gasoline exhaust and $1 \%$ in diesel exhaust. Finally, for comparison, we also computed emission factors using a method developed for the MCMA-2003 field campaign, in which we determined baseline-subtracted concentrations of all pollutants, calculated emission factors at each point in time (10-s averages) from these values, and combined the results to determine fleet averages (Jiang et al., 2005).

\section{Results}

Figure 1 displays an example 2-min time series of $\mathrm{CO}_{2}$, $\mathrm{CO}, \mathrm{NO}_{\mathrm{x}}$, benzene, and particle number measured during the drive. Concentrations vary rapidly over ranges much broader than typically seen at stationary monitoring sites. Different species are roughly correlated in time, and peaks correspond to occasions when the AML intercepted exhaust plumes from the surrounding traffic. For example, when concentrations of all species increase together at 13:13:20, the AML is merging from a side street onto a much busier thoroughfare. The large, sharp peak in all species at 13:14:41 occurs when a large tanker truck passes the AML.

The optimal number of PMF factors derived from these data is three, where one factor represents background air, the second gasoline engine exhaust, and the third diesel engine exhaust. The four- and five-factor solutions are not interpretable. In the four-factor solution, one source profile contains all the formaldehyde and no $\mathrm{CO}_{2}$, suggesting that it might represent background secondary products of atmospheric chemistry, but the time series of its contributions does not support this hypothesis. The time series has similar features to that of diesel engine exhaust. In the five-factor solution, one factor again contains all of the formaldehyde but no $\mathrm{CO}_{2}$.

The factorization is not able to distinguish between untreated gasoline exhaust and that processed by a catalytic converter. Reactions in a catalytic converter can produce ammonia incidentally, and this species therefore has the potential to be a marker of treated exhaust (Herndon et al., 2005a; Livingston et al., 2009). However, its large methodological uncertainty in this study, $50 \%$, limits its usefulness. The factorization also does not detect emissions from alternatively

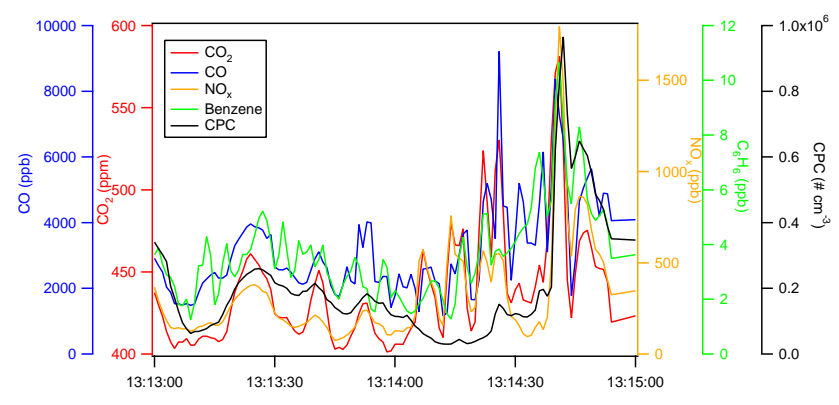

Fig. 1. $\mathrm{CO}_{2}, \mathrm{CO}, \mathrm{NO}_{\mathrm{x}}$, benzene, and particle number (CPC) time series during two minutes while driving. The AML was on a lightly trafficked side street and then encountered stopped traffic at 13:14:06. It was passed by a tanker truck at 13:14:41.

fueled vehicles using liquefied petroleum gas (LPG) or compressed natural gas (CNG). Such vehicles account for only $1 \%$ of the fleet (SMA, 2008a), so their contribution to emissions is assumed to be negligible.

In the three-factor model, all PMF runs converge, and the robust $Q$ s, from which outliers whose scaled residual exceed four are excluded, range between 185071 and 206130 . True $Q$ s vary from 366229 to 382609 . $Q$ s larger than the number of degrees of freedom are expected because of the presence of high-emitting vehicles among the population. Their dirtier emissions produce large residuals, yet must be retained in the model in order to obtain representative fleet averages.

In the G-space scatterplots, shown in the supplement (http://www.atmos-chem-phys.net/10/3629/2010/ acp-10-3629-2010-supplement.pdf), factors appear to be at least weakly independent, and anticorrelation is present between the background and gasoline exhaust factor contributions and between the background and diesel exhaust factor contributions. This relationship is expected because either vehicle exhaust or the background will dominate for most 1-s time intervals. The presence of a slight "edge" in the plot between the background and diesel factors suggests that some rotational ambiguity is present in the solution (Paatero et al., 2005). Forcing rotations by varying the FPEAK parameter between -1 and +1 , we find that values less than or equal to -0.4 improve the appearance of $\mathrm{G}$ space plots. These rotations, however, produce background $\mathrm{CO}_{2}$ levels 4-7 ppm lower than the unrotated solution's concentration of $378 \mathrm{ppm}$. Such levels are lower even than the global background; and concomitantly higher gasoline and diesel engine $\mathrm{CO}_{2}$ concentrations, which when used to calculate emission factors, result in values much lower than expected. As a portion of the on-road "background" source surely reflects regional-scale vehicle emissions, some similarities between the sources are expected, so this result is not surprising. On the basis of this analysis, we conclude that the original solution is likely to represent the most correct rotation. 


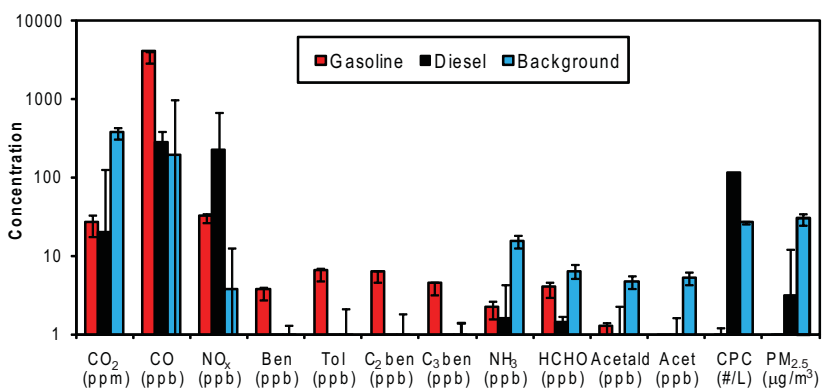

Fig. 2. Concentration profiles of gasoline, diesel, and background factors with error bars showing $95 \%$ confidence intervals. Concentration units vary by species, whose abbreviations are shown in Table 1 .

Figure 2 depicts the source profiles derived by PMF. Based on profile concentrations and factor contribution time series shown in Fig. 3, the profiles correspond to gasoline engine exhaust, diesel engine exhaust, and background sources. The identification of diesel versus gasoline exhaust is based on well-understood differences between the two that produce large contrasts in $\mathrm{CO}, \mathrm{NO}_{\mathrm{x}}, \mathrm{VOC}$, and particulate emissions. Uncertainties in the profiles probably reflect variability in emissions with driving conditions and differences between individual vehicles.

The background factor is comprised of $378 \mathrm{ppm}$ of $\mathrm{CO}_{2}$, $199 \mathrm{ppb}$ of $\mathrm{CO}, 3.7 \mathrm{ppb}$ of $\mathrm{NO}_{\mathrm{x}}, 0.5 \mathrm{ppb}$ of benzene, $0.8 \mathrm{ppb}$ of toluene, $0.6 \mathrm{ppb}$ of $\mathrm{C}_{2}$ benzenes, $0.5 \mathrm{ppb}$ of $\mathrm{C}_{3}$ benzenes, $15 \mathrm{ppb}$ of ammonia, $6.2 \mathrm{ppb}$ of formaldehyde, $4.6 \mathrm{ppb}$ of acetaldehyde, $5.2 \mathrm{ppb}$ of acetone, 26900 particles $\mathrm{cm}^{-3}$, and $30 \mu \mathrm{g} \mathrm{m}^{-3}$ of $\mathrm{PM}_{2.5}$. These levels agree well with the global background level of $\mathrm{CO}_{2}$ of $380 \mathrm{ppm}$; boundary layer $\mathrm{CO}$ and $\mathrm{NO}_{\mathrm{x}}$ concentrations of $249 \pm 110 \mathrm{ppb}$ and $3.7 \pm 5.1 \mathrm{ppb}$, respectively, measured by aircraft during the field campaign (Shon et al., 2008); and urban background $\mathrm{PM}_{2.5}$ concentrations of $25-50 \mu \mathrm{g} \mathrm{m}^{-3}$ between the hours of 11:00-14:00 during the field campaign (Querol et al., 2008). The background factor accounts for the majority of several species: $89 \%$ of $\mathrm{CO}_{2}, 80 \%$ of ammonia, $53 \%$ of formaldehyde, $70 \%$ of acetaldehyde, $81 \%$ of acetone, and $89 \%$ of $\mathrm{PM}_{2.5}$. These percentages are in agreement with the expectation that nonmobile sources are responsible for the majority of ammonia and $\mathrm{PM}_{2.5}$ and that carbonyls from secondary production will appear in the background factor. The gasoline factor has the largest concentrations of $\mathrm{CO}$ and aromatics and smallest of particle number relative to the other factors; these features are consistent with emissions from gasoline engines (Sawyer et al., 2000). On a concentration basis, the diesel factor is associated with 15 times less $\mathrm{CO}$, seven times more $\mathrm{NO}_{\mathrm{x}}$, 10-14 times less aromatics, and all of the particle counts compared to the gasoline factor. The assignment of this factor follows from previous work showing that diesel engines have lower $\mathrm{CO}$ and hydrocarbon and higher $\mathrm{NO}_{\mathrm{x}}$ and particle emission factors relative to gasoline engines (Kirchstetter et

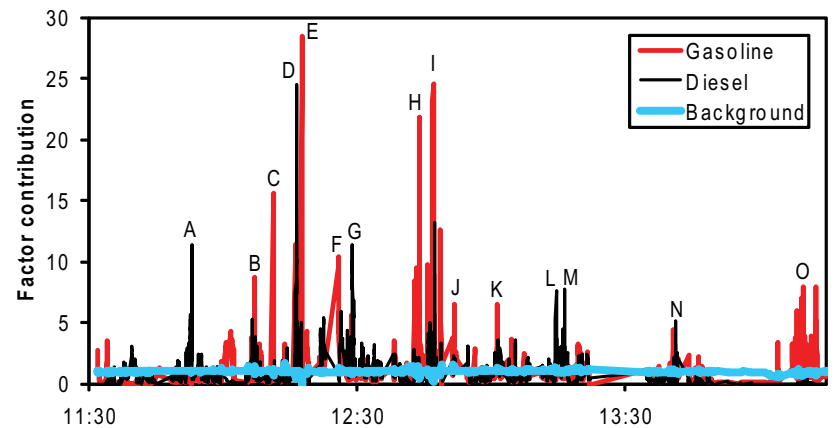

Fig. 3. Time series of PMF factor contributions; each series averages to unity. Descriptions of the video at each labeled spike appear in Table 2.

al., 1999a; Sawyer et al., 2000). We confirm the identity of the factors by examining the time series of their contributions in conjunction with the AML's video from the drive.

Figure 3 displays the time series of the factor contributions during the entire driving period. A value of one means that the contribution to a receptor at a particular point in time is equal to that averaged over the entire period. Thus, a value of five, for example, at a certain point in time means that the source represented by the factor is contributing five times as much to the observation at the receptor in that instant, compared to its contribution averaged over the entire time period. The background source's time series (thick blue line) hovers around one most of the time, while the contributions from the other gasoline and diesel sources (red and black lines) vary over a much wider range and exhibit numerous short-lived peaks. At times, the gasoline and diesel sources contribute over 20 times more than average to the observed concentrations. This behavior corresponds to the AML's sporadically intercepting exhaust plumes from surrounding vehicles with varying levels of dilution. By examining the AML's video of the view ahead of it, we can verify the identities of the factors. The 15 most prominent spikes in the figure are labeled with a letter corresponding to entries in Table 2, which describes the traffic at these points in time. In all cases, the spikes coincide with the presence of vehicles nearby, and when the diesel factor's values are large, trucks and/or buses are in view. Three of the spikes occur when the AML starts through an intersection just after the stoplight turns green. The AML may be intercepting exhaust from cross traffic that had just passed through the intersection, or it may be detecting large amounts of emissions associated with heavy accelerations of neighboring vehicles that had also been stopped at the light. While we focus on the spikes to verify the identities of the factors, in fact all data points are treated equally in the PMF analysis.

Table 3 presents fuel-based emission factors for gasolineand diesel-powered vehicles calculated from the PMF results. The column labeled "Fleet-average 2006 Gasoline" reports ranges of emission factors from gasoline-powered 
Table 2. Description of video during spikes labeled in Fig. 3.

\begin{tabular}{llll}
\hline Spike & Time & Dominant factor & Description \\
\hline A & $11: 53: 08$ & Diesel & Behind a heavy-duty truck \\
B & $12: 07: 19$ & Both & Heavy traffic at an intersection \\
C & $12: 11: 27$ & Gasoline & Starting through an intersection on a green light where cross traffic had just passed \\
D & $12: 16: 35$ & Both & Traffic with cars, a bus, and a truck \\
E & $12: 17: 46$ & Gasoline & Starting through an intersection on a green light where cross traffic had just passed \\
F & $12: 26: 02$ & Both & Accelerating from a stop in heavy traffic with cars and trucks \\
G & $12: 29: 00$ & Diesel & In moderate traffic behind a heavy-duty truck \\
H & $12: 44: 03$ & Gasoline & Behind a bus \\
I & $12: 47: 11$ & Gasoline & Starting through an intersection on a green light where cross traffic had just passed \\
J & $12: 52: 00$ & Gasoline & Close traffic with cars and buses \\
K & $13: 01: 30$ & Gasoline & Among idling cars at an intersection \\
L & $13: 14: 41$ & Diesel & In traffic next to a heavy-duty tanker truck \\
M & $13: 16: 32$ & Diesel & In traffic next to the same heavy-duty tanker truck \\
N & $13: 41: 28$ & Both & Passing a bus in traffic \\
O & $14: 09: 58$ & Gasoline & Parked on the roadside with car traffic \\
\hline
\end{tabular}

vehicles calculated across three separate driving conditions: stop-and-go, heavy traffic, and cruising (Zavala et al., 2009b). The PMF-derived emission factors for gasolinepowered vehicles fall within the range of those calculated by the fleet-average method for all species except $\mathrm{NO}_{\mathrm{x}}$, for which it is three times lower than even the lower end of the range. Reasons for the discrepancy are discussed in the following section. The true particle number emission factor for gasoline-powered vehicles is unlikely to be zero, as suggested by the PMF profiles. Rather, the 10-20\% uncertainty in the condensation particle counter's measurements dominates the expected order-of-magnitude difference in emissions between gasoline- and diesel-powered vehicles (Beddows and Harrison, 2008).

As expected, there are substantial differences in emission factors between the different fuel types. The ratios of emission factors for diesel sources relative to gasoline sources are 0.11 for $\mathrm{CO} ; 11$ for $\mathrm{NO}_{\mathrm{x}} ; 0.17$ for benzene; $0.11-0.12$ for toluene, $\mathrm{C}_{2}$ benzenes, and $\mathrm{C}_{3}$ benzenes; 1.2 for ammonia; 0.57 for formaldehyde; 0.95 for acetaldehyde; 1.3 for acetone; and 9.7 for $\mathrm{PM}_{2.5}$. Gasoline engines dominate $\mathrm{CO}$ emissions and are mainly responsible for hydrocarbons, while diesel engines dominate particle number. Emission factors for $\mathrm{NO}_{\mathrm{x}}$ and $\mathrm{PM}_{2.5}$ are $\sim 10$ times higher for diesel engines, but total emissions of these pollutants from the two engine types are closer because 3.7 times more gasoline than diesel fuel is consumed in the MCMA (SMA, 2008a). Emission factors of the carbonyls formaldehyde, acetaldehyde, and acetone are similar for the two engine types.

The last two columns of Table 3 compare emission factors for all vehicles combined, gasoline- plus diesel-powered, in 2006 and 2003, calculated using the fleet-average method presented by Jiang et al. (2005). Results calculated using the fleet-average technique illustrate differences between it and the PMF method and allow evaluation of changes in emission factors between 2003 and 2006. In 2003, measurements were averaged over 10-s blocks to handle the slower response times of the $\mathrm{CO}$ and $\mathrm{NO}_{\mathrm{x}}$ analyzers, and we have replicated this averaging in the more recently acquired data to ensure a fair comparison. For reference, the averaging results in a difference of no more than $\pm 5 \%$ for any species, except for $9 \%$ for $\mathrm{NO}_{\mathrm{x}}$, compared to emission factors calculated using raw 1-s measurements without averaging. Emission factors for all vehicles combined in 2006, calculated using the fleet-average method, lie in between the gasoline and diesel PMF-based values, as they should, for all species except formaldehyde and $\mathrm{PM}_{2.5}$. In both cases, the fleetaverage values are higher. Results for these pollutants may be confounded by secondary sources, whose concentrations can vary substantially over the day and which account for 20-70\% of formaldehyde (Garcia et al., 2006) and the majority of $\mathrm{PM}_{2.5}$ (Aiken et al., 2009) in the afternoon, and/or emissions from LPG-fueled vehicles (Zavala et al., 2006). Additionally, these two pollutants, along with ammonia, acetaldehyde, and acetone, are dominated by their background concentrations. Therefore, the concentrations assigned to the vehicle exhaust factors are especially sensitive to uncertainties in the background factor because small changes in its concentrations would have disproportionate effects on the residual available for mobile sources.

Between 2003 and 2006, combined fleet-average emission factors have decreased by $15 \%$ for $\mathrm{CO}$ and $53 \%$ for benzene but have not changed significantly for $\mathrm{NO}_{\mathrm{x}}$ or $\mathrm{PM}_{2.5}$. $\mathrm{CO}$ and benzene emissions are dominated by light-duty gasolinepowered vehicles, and a shift in the light-duty fleet to newer vehicles with better functioning catalytic converters is likely to be the reason for the change (Zavala et al., 2009b). The heavy-duty fleet, which is responsible for more of the $\mathrm{NO}_{\mathrm{x}}$ 
Table 3. Fuel-based emission factors in 2006 and 2003.

\begin{tabular}{|c|c|c|c|c|c|}
\hline $\begin{array}{l}\left(\mathrm{g} \mathrm{kg}^{-1}\right) \text { unless } \\
\text { noted }\end{array}$ & $\begin{array}{l}\text { PMF } \\
2006 \\
\text { Gasoline }^{a}\end{array}$ & $\begin{array}{l}\text { PMF } \\
2006 \\
\text { Diesel }^{\mathrm{a}}\end{array}$ & $\begin{array}{l}\text { Fleet-average } \\
2006 \\
\text { Gasoline }^{b}\end{array}$ & $\begin{array}{l}\text { Fleet-average } \\
2006 \\
\text { Combined }^{\mathrm{c}}\end{array}$ & $\begin{array}{l}\text { Fleet-average } \\
2003 \\
\text { Combined }^{\mathrm{c}}\end{array}$ \\
\hline $\mathrm{CO}$ & $\begin{array}{l}251 \\
(180,252)\end{array}$ & $\begin{array}{l}28 \\
(0,39)\end{array}$ & 89-380 & $159 \pm 14$ & $190 \pm 3$ \\
\hline $\mathrm{NO}_{\mathrm{x}}\left(\right.$ as $\left.\mathrm{NO}_{2}\right)$ & $\begin{array}{l}3.3 \\
(2.6,3.5)\end{array}$ & $\begin{array}{l}38 \\
(36,113)\end{array}$ & $10-19^{d}$ & $22 \pm 2$ & $19.0 \pm 0.2$ \\
\hline Benzene & $\begin{array}{l}0.64 \\
(0.46,0.66)\end{array}$ & $\begin{array}{l}0.11 \\
(0.03,0.13)\end{array}$ & $0.33-0.76$ & $0.28 \pm 0.03$ & $0.60 \pm 0.01$ \\
\hline Toluene & $\begin{array}{l}1.3 \\
(1.0,1.4)\end{array}$ & $\begin{array}{l}0.2 \\
(0.0,0.2)\end{array}$ & $0.5-1.7$ & $0.9 \pm 0.1$ & NA \\
\hline $\mathrm{C}_{2}$ benzenes & $\begin{array}{l}1.5 \\
(1.1,1.5)\end{array}$ & $\begin{array}{l}0.2 \\
(0.0,0.2)\end{array}$ & $0.75-1.8$ & $1.2 \pm 0.1$ & NA \\
\hline $\mathrm{C}_{3}$ benzenes & $\begin{array}{l}1.2 \\
(0.8,1.2)\end{array}$ & $\begin{array}{l}0.1 \\
(0.0,0.2)\end{array}$ & $0.5-0.9$ & $0.9 \pm 0.1$ & NA \\
\hline Formaldehyde & $\begin{array}{l}0.26 \\
(0.19,0.30)\end{array}$ & $\begin{array}{l}0.15 \\
(0.00,0.18)\end{array}$ & $0.25-0.40$ & $0.53 \pm 0.05$ & NA \\
\hline Acetaldehyde & $\begin{array}{l}0.12 \\
(0.09,0.13)\end{array}$ & $\begin{array}{l}0.11 \\
(0.07,0.36)\end{array}$ & $0.09-0.12$ & $0.13 \pm 0.01$ & NA \\
\hline Acetone & $\begin{array}{l}0.09 \\
(0.06,0.10)\end{array}$ & $\begin{array}{l}0.11 \\
(0.004,0.34)\end{array}$ & $0.04-0.09$ & $0.11 \pm 0.01$ & NA \\
\hline Ammonia & $\begin{array}{l}0.08 \\
(0.06,0.10)\end{array}$ & $\begin{array}{l}0.10 \\
(0.04,0.26)\end{array}$ & NA & $0.13 \pm 0.01$ & NA \\
\hline 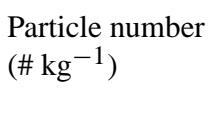 & $\begin{array}{l}0 \\
\left(0,8.5 \times 10^{13}\right)\end{array}$ & $\begin{array}{l}1.33 \times 10^{16} \\
\left(1.32 \times 10^{16},\right. \\
\left.1.33 \times 10^{16}\right)\end{array}$ & NA & $9.0 \pm 0.9 \times 10^{15}$ & NA \\
\hline $\mathrm{PM}_{2.5}{ }^{\mathrm{e}}$ & $\begin{array}{l}0.04 \\
(0.00,0.07)\end{array}$ & $\begin{array}{l}0.37 \\
(0.15,1.40)\end{array}$ & NA & $0.66 \pm 0.07$ & $0.7 \pm 1.4$ \\
\hline $\mathrm{BC}$ & $\begin{array}{l}0.0 \\
(0.0,0.0)\end{array}$ & $\begin{array}{l}1.4 \\
(1.3,1.6)\end{array}$ & NA & $0.9 \pm 0.2$ & $0.27 \pm 0.02$ \\
\hline
\end{tabular}

${ }^{a}$ Calculated from PMF-derived source profiles. Values in parentheses are $95 \%$ confidence intervals. ${ }^{b}$ Range presented for stop-and-go, traffic, and cruise conditions (Zavala et al., 2009b). ${ }^{\mathrm{c}}$ Combined gasoline and diesel fleet averages and standard errors calculated using the method of Jiang et al. (2005). ${ }^{\mathrm{d}} \mathrm{NO}$ only, converted to mass of $\mathrm{NO}_{2}$ for comparison. ${ }^{\mathrm{e}}$ This estimate does not include the additional uncertainty imposed by the limitations of the $\mathrm{PM}_{2.5}$ measurement method, as discussed in the text.

and $\mathrm{PM}_{2.5}$ emissions, has a much slower rate of turnover, and there is less room for improvement in its emissions because of the absence of control systems (e.g., catalytic converters or particle traps), that create a stark contrast between older and newer vehicles. One caveat in comparing results from the two years is that the sample composition (i.e., fraction of gasoline- versus diesel-powered vehicles) may have differed between 2003, with 75 h of driving over 13 days, and 2006, with 3.5 h over a single day.

\section{Discussion}

We have successfully applied PMF for the separation of both gasoline and diesel engine exhaust from background sources in a roadway environment at high time resolution. To subdivide the background sources, additional species are required, but among those we considered, none were able to resolve other factors. We were not able to distinguish between exhaust from gasoline-powered vehicles with catalytic converters from those without. PMF using rapid (1-s sample rate), real-time, driving data may be limited in its ability to identify positively more than three major factors in this case due to a small data set (one drive day and no particle speciation other than BC), noise levels in instruments, and various instrument time responses (as evident in Fig. 1).

A natural point of comparison for the application of PMF in the MCMA is Los Angeles, another large city in North America whose air pollution problem is dominated by vehicle emissions. PMF applied to one-hour particulate and gaseous measurements at two sites downwind of Los Angeles yielded six factors (Eatough et al., 2007; Grover and Eatough, 2008). More detailed speciation of particulate matter and the use of stationary sites rather than a mobile roadway platform, whose milieu was dominated by vehicle 
exhaust, likely enabled the resolution of more factors. In the MCMA, gasoline engine exhaust accounted for $12 \%$ of $\mathrm{NO}_{\mathrm{x}}$ and diesel for $86 \%$ (and background sources for the remaining 2\%). Downwind of Los Angeles, the diesel exhaust factor contained nearly all of the $\mathrm{NO}_{\mathrm{x}}$ associated with local mobile sources in Riverside but very little of it in Rubidoux. There, the gasoline exhaust factor contained the majority of $\mathrm{NO}_{\mathrm{x}}$, and the discrepancy is not addressed. Downwind of Los Angeles, 4-9\% of $\mathrm{PM}_{2.5}$ was attributed to gasoline vehicle sources and $11-13 \%$ to diesel, with the remaining assigned to secondary nitrate, photochemical, organic, and primary sources of emissions. In the MCMA, a smaller share of $\mathrm{PM}_{2.5}$ was apportioned to vehicular emissions: $1 \%$ to gasoline engine exhaust and $9 \%$ to diesel. In Los Angeles, all of the elemental carbon was apportioned to diesel sources, while in Mexico City, only $65 \%$ of BC was apportioned to diesel engine exhaust. The remaining $34 \%$ and $1 \%$ were apportioned to the background and gasoline exhaust, respectively. While vehicles dominate pollutant emissions in both cities, Mexico City appears to have a larger share of non-vehicular sources of combustion-related particulate emissions, perhaps from industrial activity, roadside food vendors, and biomass burning (Moffet et al., 2008).

Differences in gasoline engine emission factors, especially for $\mathrm{NO}_{\mathrm{x}}$, between the fleet-average method (Zavala et al., 2009b) and PMF method may be attributed at least partially to the inclusion of idling in the PMF analysis. The PMF-based emission factors represent a composite across all driving conditions, including idling, stop-and-go activity, and cruising along surface streets and highways. During the drive, the AML spent $17 \%$ of its time stopped in traffic, mainly at stoplights, where it was surrounded by idling vehicles. In a study in Mexicali using the AML, Zavala et al. (2009a) showed that $\mathrm{NO}_{\mathrm{x}}$ emission factors were 3-5 times lower during idling compared to other driving modes, and measurements using on-board emissions monitors in urban driving conditions found $\mathrm{NO}_{\mathrm{x}}$ emission factors to be 1.3, 2.5 , and 3.2 times lower during idling compared to accelerating, cruising, and decelerating, respectively (Tong et al., 2000). Therefore, we would expect idling-influenced emission factors to be lower than those associated with motion. For benzene, the PMF-derived emission factors fall near the upper end of the range across different driving modes determined by the fleet-average method, consistent with previous findings if idling is influencing the result. The PMF-derived emission factor for $\mathrm{CO}$ would also be expected to fall near the upper end of the range, as its value during idling, stopand-go, and low-speed driving has been found to be 2-2.5 times higher than during cruising at speeds above $56 \mathrm{~km} \mathrm{~h}^{-1}$. With a PMF-based CO emission factor of $251 \mathrm{~g} \mathrm{~kg}^{-1}$ versus a range of $89-380 \mathrm{~g} \mathrm{~kg}^{-1}$ across specific driving conditions, the numbers do not clearly support nor discredit the hypothesis about idling. Because the fuel consumption rate of vehicles is approximately three times lower when idling than while in motion, on average (Frey et al., 2003; Khan et al., 2009), idling could be overrepresented in this analysis, leading to an underestimate of $\mathrm{NO}_{\mathrm{x}}$ and overestimate of $\mathrm{CO}$ emissions. On the other hand, studies that do not correctly account for idling are subject to the opposite bias.

A remote sensing study of 11289 gasoline-powered vehicles at four sites in Mexico City in 2006 (Schifter et al., 2008) produced measurements that can be compared to the emission factors shown in Table 3. Fuel-based emission factors were not directly reported, but on the basis of emission factors reported for a similar remote sensing study in 2000 (Schifter et al., 2005) and the percent change in exhaust gas concentrations reported in 2006 relative to the year 2000, adjusted to match the vehicle specific powers in each year (Schifter et al., 2008), we calculate that $\mathrm{CO}$ and $\mathrm{NO}_{\mathrm{x}}$ emission factors in 2006 were $121 \pm 14$ and $11.1 \pm 2.6 \mathrm{~g} \mathrm{~L}^{-1}$, respectively. This calculation assumes that the fuel's carbon content and density did not change between 2000 and 2006. Adjusted to the same units using gasoline density, the $\mathrm{CO}$ emission factor quantified using the AML with PMF in 2006 is $2.1 \pm 0.4$ times higher, and the $\mathrm{NO}_{\mathrm{x}}$ emission factor is $3 \pm 1$ times lower compared to the ones measured by remote sensing.

Differences between the remote sensing and AML results may stem from the AML's ability to capture emissions during idling and stop-and-go traffic, conditions not monitored by remote sensing. As discussed above, $\mathrm{CO}$ emission factors are higher and $\mathrm{NO}_{\mathrm{x}}$ emission factors are lower during idling compared to other driving conditions (Zavala et al., 2009a), and we know from the AML's video record that at stoplights, it was surrounded by idling vehicles. Additionally, differences in driving conditions among the two studies would produce differences in the observed emissions.

Gasoline-powered vehicles in Mexico City are much dirtier, on average, than those in the US for certain pollutants but comparable for others. The CO emission factor in the MCMA is $8-13$ times higher than that measured across four sites in the US by remote sensing between 2005-2007 (Bishop and Stedman, 2008) and in the Caldecott Tunnel in the San Francisco Bay Area in 2006 (Ban-Weiss et al., 2008a). CO emission factors have fallen by a factor of four or more over the past decade in the US, so in some ways the MCMA's vehicle fleet resembles that of the US from over 10 years ago. The MCMA's carbonyl emission factors are also substantially higher than found in the US. Compared to measurements in the Caldecott Tunnel in 2006 (Ban-Weiss et al., 2008b), formaldehyde and acetaldehyde emission factors from gasoline-powered vehicles in the MCMA are 17 times higher. Fuel-based emission factors of formaldehyde do not vary significantly with driving conditions (Zavala et al., 2009a), so this species is not expected to be subject to bias associated with the inclusion of idling. Given the large differences in $\mathrm{CO}$ and aldehyde emission factors between the US and Mexico City, it seems surprising that the $\mathrm{NO}_{\mathrm{x}}$ emission factor determined by PMF is within $10 \%$ of that from the Caldecott Tunnel (Ban-Weiss et al., 2008b). However, the 
$\mathrm{NO}_{\mathrm{x}}$ emission factor we derived using the fleet-average technique (Zavala et al., 2009b) is at least three times higher than found in the US; again, the PMF-based value may represent a lower bound because of the inclusion of idling. Because of the semi-quantitative nature of the $\mathrm{PM}_{2.5}$ technique, we have omitted it from this analysis. At the very least, these comparisons suggest that there is great potential for reducing emissions of $\mathrm{CO}$ and aldehydes from gasoline-powered vehicles in the MCMA.

Much of the contrast between the two countries is probably attributable to differences in the age distribution of the vehicle fleet and in inspection and maintenance standards. Newer vehicles feature technological improvements in engine design and emissions control systems that lead to more efficient operation and reduced emissions. In the US, emission factors of vehicles that are 10-12 years old are $\sim 4$ times higher than those of vehicles five years old or younger (Bishop and Stedman, 2008). Chases of vehicles by a mobile laboratory in Macao in 2004 found CO emission factors of $230 \mathrm{~g} \mathrm{~kg}^{-1}$ for passenger cars at least 10 years old and $32 \mathrm{~g} \mathrm{~kg}^{-1}$ for newer cars, a factor of seven difference (Tang and Wang, 2006). The MCMA's policy Hoy No Circula, which restricts vehicles from driving on certain days according to their license plate numbers, may have slowed the improvement in emissions from passenger cars because some households acquire additional vehicles for use on alternating days, and these tend to be older (Davis, 2008) and therefore more polluting. Differences in emission factors may also stem from the fact that tunnel studies and remote sensing studies are restricted to a single site, in contrast to the mobile laboratory which is exposed to a larger variety of driving conditions.

Emission factors from diesel-powered vehicles in the MCMA are more similar to those found in the US. In contrast to gasoline-powered vehicles, which have been subject to strict emissions regulations, diesel-powered vehicles have not had to employ emissions control systems until very recently, so there has been considerably less variability in diesel-powered vehicle emissions over time, especially for $\mathrm{NO}_{\mathrm{x}}$ (Ban-Weiss et al., 2008b; Yanowitz et al., 2000). Measurements from the Caldecott Tunnel in 2006, Colorado in 2005, and the Squirrel Hill Tunnel in Pittsburg, Pennsylvania in 2002 produced diesel $\mathrm{NO}_{\mathrm{x}}$ emission factors of 40, 50, and $45 \mathrm{~g} \mathrm{~kg}^{-1}$, respectively (Ban-Weiss et al., 2008b; Burgard et al., 2006; Grieshop et al., 2006). The MCMA's value of $38 \mathrm{~g} \mathrm{~kg}^{-1}$ derived by PMF is similar. The agreement in the emission factor for $\mathrm{NO}_{\mathrm{x}}$, the most significant diesel-related gaseous pollutant aside from $\mathrm{CO}_{2}$, adds confidence to our results from Mexico City. Diesel emission factors for particle number are 2-3 times higher in the MCMA than in the Caldecott Tunnel (Ban-Weiss et al., 2009; Kirchstetter et al., 1999a). CO emission factors from the tunnel are highly uncertain (Harley, R., 2010, personal communication), so we exclude this species from the comparison. Emission factors of formaldehyde and acetaldehyde in the MCMA are 1.2-2.5 times higher than measured in the Caldecott Tunnel in 2006 (Ban-Weiss et al., 2008a), and that of BC is 1.7 times higher (Ban-Weiss et al., 2009). Some differences between studies may also be attributable to the use of different instrumentation, especially for particles. For example, the Caldecott study uses a water-based CPC for particle number and an aethalometer for $\mathrm{BC}$, while the AML uses a butanol-based CPC and multi-angle absorption photometer for BC. A second difference is the inclusion of idling in the PMF analysis. Diesel engine $\mathrm{NO}_{\mathrm{x}}$ and $\mathrm{BC}$ emission factors are lower during idling (Coelho et al., 2009; Huai et al., 2006; Khan et al., 2006; Shah et al., 2004; Zhai et al., 2008), but the influence is expected to be smaller than for gasoline-powered vehicles because the emission factors (fuel-based) vary less as a function of engine load.

To estimate total emissions from on-road motor vehicles, shown in Table 4, we multiply the emission factors presented in Table 3 by fuel densities of $0.732 \mathrm{~kg} \mathrm{~L}^{-1}$ for gasoline (Schifter et al., 2005) and $0.84 \mathrm{~kg} \mathrm{~L}^{-1}$ for diesel (Kirchstetter et al., 1999a) and total fuel consumption of $7.66 \times 10^{9} \mathrm{~L}$ of gasoline and $2.02 \times 10^{9} \mathrm{~L}$ of diesel fuel in the MCMA in 2006 (SMA, 2008a). The calculation assumes that the vehicles encountered during the AML's drive are representative of the MCMA's fleet, and thus our estimates are approximate. In the table, the ranges shown in parentheses are the 95\% confidence intervals, based on propagation of uncertainties associated with the emission factors shown in Table 3. For total VOCs, which were not directly measured, we scale total benzene emissions by the on-road VOC/benzene ratio obtained in 2003 (see Sect. 2). Alternatively, if we calculate VOC emissions by multiplying $\mathrm{CO}$ emissions by the VOC/CO mass ratio of $0.13-0.21$ measured in a remote sensing study in the MCMA in 2006 (Schifter et al., 2008), as done by Zavala et al. (2009b), we obtain a range which encompasses the initial estimate. Results from the present study suggest that gasoline-powered vehicles are responsible for $97 \%$ (58$98 \%$ ) of mobile source emissions of CO, $22 \%$ (18-57\%) of $\mathrm{NO}_{\mathrm{x}}, 95-97 \%(59-100 \%)$ of each aromatic species, $72-85 \%$ (43-100\%) of each carbonyl species, 74\% (44-100\%) of ammonia, negligible amounts of particle number, $26 \%(0-84 \%)$ of $\mathrm{PM}_{2.5}$, and $2 \%(0-10 \%)$ of $\mathrm{BC}$, where the values in parentheses indicate the $95 \%$ confidence interval associated with each estimate. Diesel-powered vehicles account for the balance, assuming that the contribution to emissions from the fleet's 1\% of LPG- and CNG-powered vehicles is negligible.

Because of the nature of the experiment, estimates using the AML do not include cold-start emissions, which in the US account for roughly $10 \%$ of emissions from gasolinepowered vehicles (Singer et al., 1999). In Mexico, the fractions are likely to be lower because of the reduced prevalence of catalytic converters (and thus higher running exhaust emissions). Additionally, the results may overemphasize idling conditions, possibly resulting in an underestimate of $\mathrm{NO}_{\mathrm{x}}$ and overestimate of $\mathrm{CO}$ emissions. However, estimates of the inventory that do not correctly account for 
Table 4. Total emissions in 2006 from on-road motor vehicles in Mexico City.

\begin{tabular}{|c|c|c|c|c|c|c|}
\hline \multirow{2}{*}{$\begin{array}{l}\left.\text { (metric tonnes } \mathrm{yr}^{-1}\right) \\
\text { unless noted }\end{array}$} & \multicolumn{3}{|c|}{ This study ${ }^{a}$} & \multicolumn{3}{|c|}{ Official inventory ${ }^{b}$} \\
\hline & Gasoline & Diesel & Total & Gasoline & Diesel & Total \\
\hline $\mathrm{CO}$ & $\begin{array}{l}1400000 \\
(1000000-1400000)\end{array}$ & $\begin{array}{l}48000 \\
(0-70000)\end{array}$ & $\begin{array}{l}1400000 \\
(1000000-1500000)\end{array}$ & 1717384 & 259415 & 1976799 \\
\hline $\mathrm{NO}_{\mathrm{x}}\left(\right.$ as $\left.\mathrm{NO}_{2}\right)$ & $\begin{array}{l}19000 \\
(15000-20000)\end{array}$ & $\begin{array}{l}64000 \\
(61000-191000)\end{array}$ & $\begin{array}{l}82000 \\
(78000-210000)\end{array}$ & 110824 & 48717 & 159541 \\
\hline VOC & NA & NA & $\begin{array}{l}280000 \\
(260000-280000) \\
182000-294000^{c}\end{array}$ & 158506 & 34788 & 193294 \\
\hline Benzene & $\begin{array}{l}3600 \\
(2600-3700)\end{array}$ & $\begin{array}{l}200 \\
(60-230)\end{array}$ & $\begin{array}{l}3800 \\
(2800-3900)\end{array}$ & NA & NA & 3514 \\
\hline Toluene & $\begin{array}{l}7400 \\
(5400-7700)\end{array}$ & $\begin{array}{l}300 \\
(0-300)\end{array}$ & $\begin{array}{l}7600 \\
(5600-7900)\end{array}$ & NA & NA & 14850 \\
\hline $\mathrm{C}_{2}$ benzenes & $\begin{array}{l}8200 \\
(5900-8500)\end{array}$ & $\begin{array}{l}300 \\
(0-340)\end{array}$ & $\begin{array}{l}8400 \\
(6200-8700)\end{array}$ & NA & NA & NA \\
\hline $\mathrm{C}_{3}$ benzenes & $\begin{array}{l}6500 \\
(4700-6800)\end{array}$ & $\begin{array}{l}230 \\
(0-270)\end{array}$ & $\begin{array}{l}6700 \\
(4900-7000)\end{array}$ & NA & NA & NA \\
\hline Formaldehyde & $\begin{array}{l}1500 \\
(1100-1700)\end{array}$ & $\begin{array}{l}300 \\
(0-300)\end{array}$ & $\begin{array}{l}1700 \\
(1300-1900)\end{array}$ & NA & NA & 1678 \\
\hline Acetaldehyde & $\begin{array}{l}680 \\
(480-740)\end{array}$ & $\begin{array}{l}190 \\
(110-610)\end{array}$ & $\begin{array}{l}860 \\
(660-1280)\end{array}$ & NA & NA & 541 \\
\hline Acetone & $\begin{array}{l}490 \\
(340-570)\end{array}$ & $\begin{array}{l}200 \\
(80-570)\end{array}$ & $\begin{array}{l}670 \\
(490-1060)\end{array}$ & NA & NA & NA \\
\hline Ammonia & $\begin{array}{l}460 \\
(320-550)\end{array}$ & $\begin{array}{l}160 \\
(70-440)\end{array}$ & $\begin{array}{l}620 \\
(450-910)\end{array}$ & 4201 & 150 & 4351 \\
\hline $\begin{array}{l}\text { Particle number } \\
\left(\# \mathrm{yr}^{-1}\right)\end{array}$ & $\left(0-4.8 \times 10^{17}\right)$ & $\begin{array}{l}2.3 \times 10^{19} \\
\left(2.2-2.3 \times 10^{19}\right)\end{array}$ & $\begin{array}{l}2.3 \times 10^{19} \\
\left(2.2-2.3 \times 10^{19}\right)\end{array}$ & NA & NA & NA \\
\hline $\mathrm{PM}_{2.5}$ & $\begin{array}{l}210^{\mathrm{d}} \\
(0-400)\end{array}$ & $\begin{array}{l}620^{\mathrm{d}} \\
(260-2380)\end{array}$ & $\begin{array}{l}830^{\mathrm{d}} \\
(410-2610)\end{array}$ & 842 & 2993 & 3835 \\
\hline $\mathrm{BC}$ & $\begin{array}{l}60 \\
(-130-250)\end{array}$ & $\begin{array}{l}2500 \\
(2200-2700)\end{array}$ & $\begin{array}{l}2500 \\
(2200-2800)\end{array}$ & NA & NA & NA \\
\hline
\end{tabular}

${ }^{a}$ Not including cold-start emissions. 95\% confidence interval shown in parentheses. b SMA (2008a, b). ${ }^{c}$ Alternative estimate from multiplying CO by a remote-sensing-based VOC/CO ratio of 0.13-0.21 (Schifter et al., 2008). ${ }^{\mathrm{d}}$ This estimate does not include the additional uncertainty imposed by the limitations of the $\mathrm{PM}_{2.5}$ measurement method, as discussed in the text.

emissions during idling may produce bias in the opposite direction. Idling is estimated to account for 5-9\% of fuel consumption by light-duty vehicles (Frey et al., 2003; Carrico et al., 2009).

Compared with the official mobile source inventory (SMA, 2008a,b), shown in Table 4, our estimates of emissions of $\mathrm{CO}$ and $\mathrm{NO}_{\mathrm{x}}$ are lower while our estimates of VOCs are higher. Using the fleet-average approach and a larger sample size, we (Zavala et al., 2009b) reached a similar conclusion for the gasoline-powered portion of the inventory. $\mathrm{CO}$ emissions predicted by this study are $26 \%$ lower than the official inventory's, and even if we increase our estimate by $10 \%$ to account for cold starts, the upper limit of the $95 \%$ confidence interval still falls below the official inventory's value. Our VOC estimate is $46 \%$ higher than that in the official inventory. Adding cold starts and evaporative emissions would exacerbate the discrepancy, strongly suggesting that the official inventory underestimates VOC emissions. Our
$\mathrm{NO}_{\mathrm{x}}$ emissions are $48 \%$ lower than those in the official inventory, but the addition of cold starts and consideration of idling could bring the two estimates closer together. However, even if we multiply the gasoline-related $\mathrm{NO}_{\mathrm{x}}$ emissions by a factor of three (to agree with results from fleet-average and remote sensing techniques), the new total emissions would still fall $24 \%$ below the official inventory. In contrast with $\mathrm{CO}$, for which the discrepancy falls in the same direction for both gasoline- and diesel-powered vehicles, with $\mathrm{NO}_{\mathrm{x}}$, the discrepancy lies in opposite directions for each of the two vehicle types. Compared to the official inventory, our inventory is $83 \%$ lower for gasoline-powered vehicles and $31 \%$ higher for diesel-powered ones. Emissions of formaldehyde and benzene agree well between the two inventories, while ours contains less ammonia, more acetaldehyde, and less toluene than does the official one. The PMF-based estimate of $\mathrm{PM}_{2.5}$ emissions is nearly five times lower than the official inventory's, but confidence in the comparison is not 
high because of uncertainties in the light-scattering method used in this study for quantifying $\mathrm{PM}_{2.5}$. Meanwhile, measurements of organic $\mathrm{PM}_{1}$ suggest that $\mathrm{PM}_{2.5}$ in the official inventory is severely underestimated (Zavala et al., 2009b). Clearly, future research should be devoted to the accurate measurement of $\mathrm{PM}_{2.5}$ from mobile sources in the MCMA.

Comparison of ratios of different species in the inventory to ambient measurements in the morning (6:00-9:00) at urban sites can provide independent verification of the inventory. While total VOC results are not yet available from 2006, ambient urban measurements during the morning hours from the MCMA-2003 field campaign (Velasco et al., 2007) can help illuminate the conditions. Our inventory's VOC/CO mass ratio of 0.19 is closer to the ambient ratio of 0.25 than is the official inventory's ratio of 0.10 , and our $\mathrm{VOC} / \mathrm{NO}_{\mathrm{x}}$ ratio of 3.4 is closer to the ambient ratio of 5.4 than is the official inventory's ratio of 1.2. Our $\mathrm{NO}_{\mathrm{x}} / \mathrm{CO}$ mass ratio of 0.057 does not agree as well with the ambient ratio of 0.075 (Stephens et al., 2008; Wood et al., 2009; Zavala et al., $2009 \mathrm{~b}$ ) as does the official inventory's ratio of 0.081 . However, both the PMF-derived inventory for all mobile sources and the fleet-average-derived one for gasoline-powered vehicles only (Zavala et al., 2009b) estimate that emissions of $\mathrm{CO}$ and $\mathrm{NO}_{\mathrm{x}}$ are lower than in the official inventory, so the $\mathrm{NO}_{\mathrm{x}} / \mathrm{CO}$ ratio in the official inventory should be viewed with some skepticism.

Employing a variety of techniques, other studies have also evaluated the MCMA's emission inventory. Most agree that $\mathrm{CO}$ is overstated, VOCs are understated, and $\mathrm{NO}_{\mathrm{x}}$ may be overstated in the official inventory. Historically, the official inventory has been a moving target because of updates in methodology (Molina and Molina, 2002), so conclusions may depend on the specific year used for comparison. For $\mathrm{CO}$, whose emissions are dominated by motor vehicles, roadside remote sensing measurements of vehicle exhaust produce emissions estimates that are $48 \%$ lower than in the official 1998 inventory (Schifter et al., 2005). On-road measurements using the AML suggest that the official inventories in 2002 and 2006 also overestimate CO by $20-38 \%$ (Jiang et al., 2005; Zavala et al., 2009b). However, modeling results using the 2002 inventory suggest that it is correct (de Foy et al., 2007). For VOCs, on-road measurements using the AML produce estimates of mobile source VOC emissions that are 1.3-1.9 times higher than in the 2002 inventory. Obtaining agreement between ambient concentrations and emission inventory ratios and between photochemical air quality modeling predictions and observations requires increasing total VOC emissions in the 1998 and 2002 inventories by factors of 2-3 (Arriaga-Colina et al., 2004; West et al., 2004) and 1.7 (Lei et al., 2007), respectively. For $\mathrm{NO}_{\mathrm{x}}$, measurements by both remote sensing and the AML result in estimates of vehicle emissions that are comparable to or up to $26 \%$ lower than in the 1998, 2002, and 2006 official mobile source inventories (Jiang et al., 2005; Schifter et al., 2005; Zavala et al., 2006, 2009b). In spite of the small sample size in the present work, comparisons to the official emission inventory for these three pollutants are in agreement with results from other studies.

Measurement-based estimates of total vehicular $\mathrm{CO}$, VOC, $\mathrm{NO}_{\mathrm{x}}$, ammonia, acetaldehyde, and acetone emissions in the MCMA 2006 are not significantly different from those calculated for 2003 (Jiang et al., 2005; Zavala et al., 2006), while estimates of formaldehyde and toluene emissions are significantly lower for 2006 compared to 2003. Although fuel-based emission factors of $\mathrm{CO}$ and benzene, and by implication VOCs, are lower in 2006 (Table 3), growth in fuel consumption over the three years $-12 \%$ for gasoline and $35 \%$ for diesel - partially offsets a cleaner fleet. Separating gasoline from diesel sources, as we did in 2006, should be more accurate than the method used in 2003 (Jiang et al., 2005), which lumped all vehicles together. Lumped emission factors could be skewed by observations from dieselpowered vehicles, and then multiplying by total (gasoline plus diesel) fuel consumption would result in an overestimation of emissions. To reduce total motor vehicle emissions, improvement in the fleet's emission factors, for example through stricter inspection and maintenance programs, must outpace growth in fuel consumption.

\section{Conclusions}

We have measured pollutant concentrations along Mexico City's roadways using fast-response instruments on board a mobile laboratory. Applying PMF to the measurements, we successfully identified three factors: gasoline engine exhaust, diesel engine exhaust, and background. We were not able to isolate treated gasoline exhaust from raw nor to resolve multiple background factors. From the source profiles, we calculated emission factors of $\mathrm{CO}, \mathrm{NO}_{\mathrm{x}}$, formaldehyde, acetaldehyde, acetone, benzene, toluene, $\mathrm{C}_{2}$ benzenes, $\mathrm{C}_{3}$ benzenes, ammonia, particle number, $\mathrm{PM}_{2.5}$, and $\mathrm{BC}$. Because the AML spent $17 \%$ of its time idling at traffic lights during the experiment, idling may be overrepresented in the emission factors reported here, and some species are especially sensitive to driving conditions (e.g., $\mathrm{NO}_{\mathrm{x}}$ is lower than expected). These results emphasize the importance of correctly accounting for idling in measurements of emissions and estimates of mobile source inventories. Because of the small sample size in this study, the conclusions presented below apply to the fleet sampled during $3.5 \mathrm{~h}$ of driving and may not necessarily pertain to the MCMA's fleet as a whole.

The MCMA's gasoline-powered vehicles are considerably dirtier, on average, than those in the US with respect to $\mathrm{CO}$ and aldehydes. Its diesel-powered vehicles have similar emission factors of $\mathrm{NO}_{\mathrm{x}}$ and higher emission factors of aldehydes, particle number, and BC. In the fleet sampled during AML driving, gasoline-powered vehicles are found to be responsible for $97 \%$ (58-98\%) of mobile source emissions of $\mathrm{CO}, 22 \%(18-57 \%)$ of $\mathrm{NO}_{\mathrm{x}}, 95-97 \%$ (59- 
$100 \%)$ of each aromatic species, $72-85 \%(43-100 \%)$ of each carbonyl species, $74 \%$ (44-100\%) of ammonia, negligible amounts of particle number, 26\% (0-84\%) of $\mathrm{PM}_{2.5}$, and $2 \%(0-10 \%)$ of $\mathrm{BC}$, where the values in parentheses indicate the $95 \%$ confidence interval associated with each estimate. Diesel-powered vehicles account for the balance, assuming that the contribution from LPG- and CNG-fueled vehicles is negligible. The resulting fuel-based estimates of emissions are lower the official inventory for $\mathrm{CO}$ and $\mathrm{NO}_{\mathrm{x}}$ and higher for VOCs. For $\mathrm{NO}_{\mathrm{x}}$, the fuel-based inventory is lower for gasoline-powered vehicles but higher for diesel-powered ones compared to the official inventory. While conclusions regarding the inventory should be interpreted with care because of the small sample size, the discrepancies agree with those reported in other studies. Accurate on-road measurements of $\mathrm{PM}_{2.5}$ from vehicular sources are sorely needed to validate the inventory. As the MCMA's vehicle fleet is considerably dirtier than the US's for certain pollutants, there is much potential for improvement in emission factors. Progress will be needed to offset growth in fuel consumption.

PMF appears to be a promising approach for deriving gasoline- and diesel-powered vehicle emission factors from on-road studies employing fast measurement systems. Future studies of exhaust emissions should be designed to overcome some of the limitations identified in this work. We recommend the capture of larger data sets, so that PMF can be applied to subsets of variable sizes to determine the sensitivity of derived factor characterizations and quantitative emission factors to the size of the data pool, and more detailed particle speciation with fast-response instrumentation. We also suggest focusing on those species whose on-road concentrations are not dominated by the background, unless expected background concentrations are well constrained by independent measurements. Successful resolution of more factors, such as emissions associated with different fuels and/or exhaust control technologies, requires measurement uncertainty smaller than the expected difference between the emission factors. Ideally, the variation in background pollutant concentrations, including those of secondary origin, will be small over the duration of the experiments.

Acknowledgements. We thank the US National Science Foundation (ATM-0528170 and ATM-0528227), the US Department of Energy (DE-FG02-05ER63982), and the National Aeronautics and Space Administration for financial support. This study was also supported by the Molina Center for Strategic Studies in Energy and the Environment. D. Thornhill was supported by a Fulbright Fellowship, and A. Williams was supported by a National Science Foundation Graduate Research Fellowship. We thank I. Deustua, K. Gutierrez, and G. Sosa for their assistance with the field campaign and analysis and three anonymous reviewers for their insightful suggestions.

Edited by: S. Madronich

\section{References}

Aiken, A. C., Salcedo, D., Cubison, M. J., Huffman, J. A., DeCarlo, P. F., Ulbrich, I. M., Docherty, K. S., Sueper, D., Kimmel, J. R., Worsnop, D. R., Trimborn, A., Northway, M., Stone, E. A., Schauer, J. J., Volkamer, R. M., Fortner, E., de Foy, B., Wang, J., Laskin, A., Shutthanandan, V., Zheng, J., Zhang, R., Gaffney, J., Marley, N. A., Paredes-Miranda, G., Arnott, W. P., Molina, L. T., Sosa, G., and Jimenez, J. L.: Mexico City aerosol analysis during MILAGRO using high resolution aerosol mass spectrometry at the urban supersite (T0) - Part 1: Fine particle composition and organic source apportionment, Atmos. Chem. Phys., 9, 66336653, 2009,

http://www.atmos-chem-phys.net/9/6633/2009/.

Arriaga-Colina, J. L., West, J. J., Sosa, G., Escalona, S. S., Ordunez, R. M., and Cervantes, A. D. M.: Measurements of VOCs in Mexico City (1992-2001) and evaluation of VOCs and CO in the emissions inventory, Atmos. Environ., 38, 2523-2533, 2004.

Ban-Weiss, G. A., McLaughlin, J. P., Harley, R. A., Kean, A. J., Grosjean, E., and Grosjean, D.: Carbonyl and nitrogen dioxide emissions from gasoline- and diesel-powered motor vehicles, Environ. Sci. Technol., 42, 3944-3950, 2008a.

Ban-Weiss, G. A., McLaughlin, J. P., Harley, R. A., Lunden, M. M., Kirchstetter, T. W., Kean, A. J., Strawa, A. W., Stevenson, E. D., and Kendall, G. R.: Long-term changes in emissions of nitrogen oxides and particulate matter from on-road gasoline and diesel vehicles, Atmos. Environ., 42, 220-232, 2008b.

Ban-Weiss, G. A., Lunden, M. M., Kirchstetter, T. W., and Harley, R. A.: Measurement of black carbon and particle number emission factors from individual heavy-duty trucks, Environ. Sci. Technol., 43, 1419-1424, 2009.

Beddows, D. C. S. and Harrison, R. M.: Comparison of average particle number emission factors for heavy and light duty vehicles derived from rolling chassis dynamometer and field studies, Atmos. Environ., 42, 7954-7966, 2008.

Bishop, G. A. and Stedman, D. H.: A decade of on-road emissions measurements, Environ. Sci. Technol., 42, 1651-1656, 2008.

Burgard, D. A., Bishop, G. A., Stedman, D. H., Gessner, V. H., and Daeschlein, C.: Remote sensing of in-use heavy-duty diesel trucks, Environ. Sci. Technol., 40, 6938-6942, 2006.

Canagaratna, M. R., Jayne, J. T., Ghertner, D. A., Herndon, S., Shi, Q., Jimenez, J. L., Silva, P. J., Williams, P., Lanni, T., Drewnick, F., Demerjian, K. L., Kolb, C. E., and Worsnop, D. R.: Chase studies of particulate emissions from in-use New York City vehicles, Aerosol Sci. Tech., 38, 555-573, 2004.

Carrico, A. R., Padgett, P., Vandenbergh, M. P., Gilligan, J., and Wallston, K. A.: Costly myths: An analysis of idling beliefs and behavior in personal motor vehicles, Energ. Policy, 37, 28812888, 2009.

Coelho, M. C., Frey, H. C., Rouphail, N. M., Zhai, H., and Pelkmans, L.: Assessing methods for comparing emissions from gasoline and diesel light-duty vehicles based on microscale measurements, Transport. Res. D-Tr. E., 14, 91-99, 2009.

Davis, L. W.: The effect of driving restrictions on air quality in Mexico City, J. Polit. Econ., 116, 38-81, 2008.

de Foy, B., Lei, W., Zavala, M., Volkamer, R., Samuelsson, J., Mellqvist, J., Galle, B., Martínez, A.-P., Grutter, M., Retama, A., and Molina, L. T.: Modelling constraints on the emission inventory and on vertical dispersion for $\mathrm{CO}$ and $\mathrm{SO}_{2}$ in the Mexico City Metropolitan Area using Solar FTIR and zenith sky UV spec- 
troscopy, Atmos. Chem. Phys., 7, 781-801, 2007,

http://www.atmos-chem-phys.net/7/781/2007/.

Eatough, D. J., Grover, B. D., Woolwine, W. R., Eatough, N. L., Long, R., and Farber, R.: Source apportionment of $1 \mathrm{~h}$ semicontinuous data during the 2005 Study of Organic Aerosols in Riverside (SOAR) using positive matrix factorization, Atmos. Environ., 42, 2706-2719, 2007.

Frey, H. C., Unal, A., Rouphail, N. M., and Colyar, J. D.: On-road measurement of vehicle tailpipe emissions using a portable instrument, J. Air Waste Manage., 53, 992-1002, 2003.

Garcia, A. R., Volkamer, R., Molina, L. T., Molina, M. J., Samuelson, J., Mellqvist, J., Galle, B., Herndon, S. C., and Kolb, C. E.: Separation of emitted and photochemical formaldehyde in Mexico City using a statistical analysis and a new pair of gas-phase tracers, Atmos. Chem. Phys., 6, 4545-4557, 2006,

http://www.atmos-chem-phys.net/6/4545/2006/.

Grieshop, A. P., Lipsky, E. M., Pekney, N. J., Takahama, S., and Robinson, A. L.: Fine particle emission factors from vehicles in a highway tunnel: Effects of fleet composition and season, Atmos. Environ., 40, 287-298, 2006.

Grover, B. D. and Eatough, D. J.: Source apportionment of onehour semi-continuous data using positive matrix factorization with total mass (nonvolatile plus semi-volatile) measured by the R\&P FDMS monitor, Aerosol Sci. Tech., 42, 28-39, 2008.

Herndon, S. C., Jayne, J. T., Zahniser, M., Worsnop, D. R., Knighton, B., Alwine, E., Lamb, B. K., Zavala, M., Nelson, D. D., McManus, J. B., Shorter, J. H., Canagaratna, M., Onasch, T. B., and Kolb, C. E.: Characterization of urban pollutant emission fluxes and ambient concentration distributions using a mobile laboratory with rapid response instrumentation, Faraday Discuss., 130, 327-339, 2005a.

Herndon, S. C., Shorter, J. H., Zahniser, M. S., Worsnop, D. R., Nelson, D. D., Demerjian, K. L., and Kolb, C. E.: Real-time measurements of $\mathrm{SO}_{2}, \mathrm{H}_{2} \mathrm{CO}$, and $\mathrm{CH}_{4}$ emissions from in-use curbside passenger buses in New York City using a chase vehicle, Environ. Sci. Technol., 20, 7984-7990, 2005b.

Huai, T., Shah, S. D., Miller, J. W., Younglove, T., Chernich, D. J., and Ayala, A.: Analysis of heavy-duty diesel truck activity and emissions data, Atmos. Environ., 40, 2333-2344, 2006.

Jiang, M., Marr, L. C., Dunlea, E. J., Herndon, S. C., Jayne, J. T., Kolb, C. E., Knighton, W. B., Rogers, T. M., Zavala, M., Molina, L. T., and Molina, M. J.: Vehicle fleet emissions of black carbon, polycyclic aromatic hydrocarbons, and other pollutants measured by a mobile laboratory in Mexico City, Atmos. Chem. Phys., 5, 3377-3387, 2005, http://www.atmos-chem-phys.net/5/3377/2005/.

Khan, A., Clark, N. N., Thompson, G. J., Wayne, W. S., Gautam, M., Lyons, D. W., and Hawelti, D.: Idle emissions from heavy-duty diesel vehicles: Review and recent data, J. Air Waste Manage., 56, 1404-1419, 2006.

Khan, A. B., Clark, N. N., Gautam, M., Wayne, W. S., Thompson, G. J., and Lyons, D. W.: Idle emissions from medium heavyduty diesel and gasoline trucks, J. Air Waste Manage., 59, 354359, 2009.

Kim, E., Hopke, P. K., and Edgerton, E. S.: Improving source identification of Atlanta aerosol using temperature resolved carbon fractions in positive matrix factorization, Atmos. Environ., 38, 3349-3362, 2004.

Kirchstetter, T. W., Harley, R. A., Kreisberg, N. M., Stolzen- burg, M. R., and Hering, S. V.: On-road measurement of fine particle and nitrogen oxide emissions from light- and heavy-duty motor vehicles, Atmos. Environ., 33, 2955-2968, 1999a.

Kirchstetter, T. W., Singer, B. C., Harley, R. A., Kendall, G. R., and Traverse, M.: Impact of California reformulated gasoline on motor vehicle emissions, 1. Mass emission rates, Environ. Sci. Technol., 33, 318-328, 1999b.

Kolb, C. E., Herndon, S. C., McManus, J. B., Shorter, J. H., Zahniser, M. S., Nelson, D. D., Jayne, J. T., Carnagaranta, M. R., and Worsnop, D. R.: Mobile laboratory with rapid response instruments for real-time measurements of urban and regional trace gas and particulate distributions and emission source characteristics, Environ. Sci. Technol., 38, 5694-5703, 2004.

Larsen, R. K. and Baker, J. E.: Source apportionment of polycyclic aromatic hydrocarbons in the urban atmosphere: a comparison of three methods, Environ. Sci. Technol., 37, 1873-1881, 2003.

Lee, J. H., Hopke, P. K., and Turner, J. R.: Source identification of airborne $\mathrm{PM}_{2.5}$ at the St. Louis-Midwest Supersite, J. Geophys. Res., 111, D10S10, doi:10.1029/2005JD006329, 2006.

Lei, W., de Foy, B., Zavala, M., Volkamer, R., and Molina, L. T.: Characterizing ozone production in the Mexico City Metropolitan Area: a case study using a chemical transport model, Atmos. Chem. Phys., 7, 1347-1366, 2007,

http://www.atmos-chem-phys.net/7/1347/2007/.

Livingston, C., Rieger, P., and Winer, A.: Ammonia emissions from a representative in-use fleet of light and medium-duty vehicles in the California South Coast Air Basin, Atmos. Environ., 43, 3326-3333, 2009.

Marr, L. C., Black, D. R., and Harley, R. A.: Formation of photochemical air pollution in central California 1. Development of a revised motor vehicle emission inventory, J. Geophys. Res., 107, D4047, doi:10.1029/2001JD000689, 2002.

Moffet, R. C., de Foy, B., Molina, L. T., Molina, M. J., and Prather, K. A.: Measurement of ambient aerosols in northern Mexico City by single particle mass spectrometry, Atmos. Chem. Phys., 8, 4499-4516, 2008, http://www.atmos-chem-phys.net/8/4499/2008/.

Molina, L. T. and Molina, M. J.: Air Quality in the Mexico Megacity: An Integrated Assessment, Kluwer Academic Publishers, Dordrecht, 2002.

Nelson, D. D., McManus, B., Urbanski, S., Herndon, S., and Zahniser, M. S.: High precision measurements of atmospheric nitrous oxide and methane using thermoelectrically cooled midinfrared quantum cascade lasers and detectors, Spectrochim. Acta A, 60, 3325-3335, 2004.

Paatero, P.: The Multilinear Engine - a table-driven least squares program for solving multilinear problems, including the $n$-way parallel factor analysis model, J. Comput. Graph. Stat., 8, 854888, 1999.

Paatero, P. and Hopke, P. K.: Discarding or downweighting highnoise variables in factor analytic models, Anal. Chim. Acta, 490, 277-289, 2003.

Paatero, P., Hopke, P. K., Begum, B. A., and Biswas, S. K.: A graphical diagnostic method for assessing the rotation in factor analytical models of atmospheric pollution, Atmos. Environ., 39, 193201, 2005.

Paterson, K. G., Sagady, J. L., and Hooper, D. L.: Analysis of air quality data using positive matrix factorization, Environ. Sci. Technol., 33, 635-641, 1999. 
Pekney, N. J., Davidson, C. I., Robinson, A., Zhou, L. M., Hopke, P., Eatough, D., and Rogge, W. F.: Major source categories for $\mathrm{PM}_{2.5}$ in Pittsburgh using PMF and UNMIX, Aerosol Sci. Tech., 40, 910-924, 2006.

Petzold, A. and Schonlinner, M.: Multi-angle absorption photometer - A new method for the measurement of aerosol light absorption and atmospheric black carbon, J. Aerosol Sci., 35, 421-441, 2004.

Querol, X., Pey, J., Minguillón, M. C., Pérez, N., Alastuey, A., Viana, M., Moreno, T., Bernabé, R. M., Blanco, S., Cárdenas, B., Vega, E., Sosa, G., Escalona, S., Ruiz, H., and Artíñano, B.: PM speciation and sources in Mexico during the MILAGRO-2006 Campaign, Atmos. Chem. Phys., 8, 111-128, 2008, http://www.atmos-chem-phys.net/8/111/2008/.

Reff, A., Eberly, S. I., and Bhave, P. V.: Receptor modeling of ambient particulate matter data using positive matrix factorization: review of existing methods, J. Air Waste Manage., 57, 146-154, 2007.

Rogers, T. M., Grimsrud, E. R., Herndon, S. C., Jayne, J. T., Kolb, C. E., Allwine, E., Westberg, H., Lamb, B. K., Zavala, M., Molina, L. T., Molina, M. J., and Knighton, W. B.: On-road measurements of volatile organic compounds in the Mexico City metropolitan area using proton transfer reaction mass spectrometry, Int. J. Mass Spectrom., 252, 26-37, 2006.

Sawyer, R. F., Harley, R. A., Cadle, S. H., Norbeck, J. M., Slott, R., and Bravo, H. A.: Mobile sources critical review: 1998 NARSTO assessment, Atmos. Environ., 34, 2161-2181, 2000.

Schifter, I., Diaz, L., Mugica, V., and Lopez-Salinas, E.: Fuel-based motor vehicle emission inventory for the metropolitan area of Mexico city, Atmos. Environ., 39, 931-940, 2005.

Schifter, I., Diaz, L., Rodriguez, R., Duran, J., and Chavez, O.: Trends in exhaust emissions from in-use Mexico City vehicles, 2000-2006, A remote sensing study, Environ. Monit. Assess., 137, 459-470, 2008.

Shah, S. D., Cocker, D. R., Miller, J. W., and Norbeck, J. M.: Emission rates of particulate matter and elemental and organic carbon from in-use diesel engines, Environ. Sci. Technol., 38, 25442550, 2004.

Shon, Z.-H., Madronich, S., Song, S.-K., Flocke, F. M., Knapp, D. J., Anderson, R. S., Shetter, R. E., Cantrell, C. A., Hall, S. R., and Tie, X.: Characteristics of the $\mathrm{NO}-\mathrm{NO}_{2}-\mathrm{O}_{3}$ system in different chemical regimes during the MIRAGE-Mex field campaign, Atmos. Chem. Phys., 8, 7153-7164, 2008,

http://www.atmos-chem-phys.net/8/7153/2008/.

Shorter, J. H., Herndon, S., Zahniser, M. S., Nelson, D. D., Wormhoudt, J., Demerjian, K. L., and Kolb, C. E.: Real-time measurements of nitrogen oxide emissions from in-use New York City transit buses using a chase vehicle, Environ. Sci. Technol., 39, 7991-8000, 2005.

Shrivastava, M. K., Subramanian, R., Rogge, W. F., and Robinson, A. L.: Sources of organic aerosol: Positive matrix factorization of molecular marker data and comparison of results from different source apportionment models, Atmos. Environ., 41, 93539369, 2007.

Singer, B. C., Kirchstetter, T. W., Harley, R. A., Kendall, G. R., and Hesson, J. M.: A fuel-based approach to estimating motor vehicle cold-start emissions, J. Air Waste Manage., 49, 125-135, 1999.

Singer, B. C. and Harley, R. A.: A fuel-based inventory of motor ve- hicle exhaust emissions in the Los Angeles area during summer 1997, Atmos. Environ., 34, 1783-1795, 2000.

SMA (Secretaria del Medio Ambiente del Distrito Federal): Inventario de emisiones criterio para el año de 2006 de la Zona Metropolitana del Valle de México, Secretaría del Medio Ambiente, Gobierno de México, México, 2008a.

SMA (Secretaria del Medio Ambiente del Distrito Federal): Inventario de emisiones toxicas para el año de 2006 de la Zona Metropolitana del Valle de México, Secretaría del Medio Ambiente, Gobierno de México, México, 2008b.

Stephens, S., Madronich, S., Wu, F., Olson, J. B., Ramos, R., Retama, A., and Muñoz, R.: Weekly patterns of Mxico City's surface concentrations of $\mathrm{CO}, \mathrm{NO}_{\mathrm{x}}, \mathrm{PM}_{10}$ and $\mathrm{O}_{3}$ during 19862007, Atmos. Chem. Phys., 8, 5313-5325, 2008,

http://www.atmos-chem-phys.net/8/5313/2008/.

Tang, U. W. and Wang, Z.: Determining gaseous emission factors and driver's particle exposures during traffic congestion by vehicle-following measurement techniques, J. Air Waste Manage., 56, 1532-1539, 2006.

Tong, H. Y., Hung, W. T., and Cheung, C. S.: On-road motor vehicle emissions and fuel consumption in urban driving conditions, J. Air Waste Manage., 50, 543-554, 2000.

Velasco, E., Lamb, B., Westberg, H., Allwine, E., Sosa, G., ArriagaColina, J. L., Jobson, B. T., Alexander, M. L., Prazeller, P., Knighton, W. B., Rogers, T. M., Grutter, M., Herndon, S. C., Kolb, C. E., Zavala, M., de Foy, B., Volkamer, R., Molina, L. T., and Molina, M. J.: Distribution, magnitudes, reactivities, ratios and diurnal patterns of volatile organic compounds in the Valley of Mexico during the MCMA 2002 \& 2003 field campaigns, Atmos. Chem. Phys., 7, 329-353, 2007,

http://www.atmos-chem-phys.net/7/329/2007/.

West, J. J., Zavala, M. A., Molina, L. T., Molina, M. J., San Martini, F., McRae, G. J., Sosa-Iglesias, G., and Arriaga-Colina, J. L.: Modeling ozone photochemistry and evaluation of hydrocarbon emissions in the Mexico City metropolitan area, J. Geophys. Res., 109, D19312, doi:10.1029/2004jd004614, 2004.

Wood, E. C., Herndon, S. C., Onasch, T. B., Kroll, J. H., Canagaratna, M. R., Kolb, C. E., Worsnop, D. R., Neuman, J. A., Seila, R., Zavala, M., and Knighton, W. B.: A case study of ozone production, nitrogen oxides, and the radical budget in Mexico City, Atmos. Chem. Phys., 9, 2499-2516, 2009, http://www.atmos-chem-phys.net/9/2499/2009/.

Yanowitz, J., McCormick, R. L., and Graboski, M. S.: In-use emissions from heavy-duty diesel vehicles, Environ. Sci. Technol., 34, 729-740, 2000.

Zavala, M., Herndon, S. C., Slott, R. S., Dunlea, E. J., Marr, L. C., Shorter, J. H., Zahniser, M., Knighton, W. B., Rogers, T. M., Kolb, C. E., Molina, L. T., and Molina, M. J.: Characterization of on-road vehicle emissions in the Mexico City Metropolitan Area using a mobile laboratory in chase and fleet average measurement modes during the MCMA-2003 field campaign, Atmos. Chem. Phys., 6, 5129-5142, 2006, http://www.atmos-chem-phys.net/6/5129/2006/.

Zavala, M., Herndon, S. C., Wood, E. C., Jayne, J. T., Nelson, D. D., Trimborn, A. M., Dunlea, E., Knighton, W. B., Mendoza, A., Allen, D. T., Kolb, C. E., Molina, M. J., and Molina, L. T.: Comparison of emissions from on-road sources using a mobile laboratory under various driving and operational sampling modes, Atmos. Chem. Phys., 9, 1-14, 2009a, 
http://www.atmos-chem-phys.net/9/1/2009/.

Zavala, M., Herndon, S. C., Wood, E. C., Onasch, T. B., Knighton, W. B., Marr, L. C., Kolb, C. E., and Molina, L. T.: Evaluation of mobile emissions contributions to Mexico City's emissions inventory using on-road and cross-road emission measurements and ambient data, Atmos. Chem. Phys., 9, 6305-6317, 2009b, http://www.atmos-chem-phys.net/9/6305/2009/.
Zhai, H. B., Frey, H. C., and Rouphail, N. M.: A vehicle-specific power approach to speed- and facility-specific emissions estimates for diesel transit buses, Environ. Sci. Technol., 42, 79857991, 2008. 